\title{
PROPORTION AND GALECTIN 3 EXPRESSION OF THYROID MALIGNANCIES DEVELOPING IN MULTINODULAR GOITER
}

\author{
Sreeja K1, Lillykutty Pothen², Sankar $S^{3}$
}

${ }_{1}^{1}$ Resident, Department of Pathology, Government Medical College, Kottayam, Kerala, India.

${ }^{2}$ Additional Professor, Department of Pathology, Government Medical College, Kottayam, Kerala, India.

3 Professor and HOD, Department of Pathology, Government Medical College, Kottayam, Kerala, India.

\begin{tabular}{l}
\hline ABSTRACT \\
\hline BACKGROUND \\
Multinodular goiter (MNG) is traditionally thought to be a benign disease with an incidence of malignancy of less than $5 \%$, as \\
compared to a solitary nodule of thyroid. Recent studies, however, suggest a higher risk of malignancy in patients with \\
multinodular goiter (7-17\%). The most common malignancy developing in MNG is papillary carcinoma. Several \\
immunohistochemical markers are used to complement histopathological examination. Galectin-3 is a marker that is expressed in \\
the malignant lesions of thyroid and its expression will help in the histological typing of the malignancies.
\end{tabular}

\section{MATERIALS AND METHODS}

This is a descriptive study done on all the specimens of multinodular goiter received in the Department of Pathology, Kottayam during the study period of one year. A total of 510 multinodular goiters specimens were studied. Histopathological examination of all the multinodular goiter specimens was done. Immunostaining for Galectin 3 expression (Gal-3) was also done. Multivariate analysis and logistical regression analysis were done.

\section{RESULTS}

Of 510 multinodular goiters, 49 cases (9.6\%) had malignancy, constituted by 44 cases of papillary thyroid carcinoma, 3 cases of follicular carcinoma, one case each of anaplastic and poorly differentiated carcinoma. Gal-3 expression was positive in $79.6 \%$ of the malignancies. $82 \%$ of papillary thyroid carcinoma, $33 \%$ of follicular carcinoma and the cases of anaplastic and poorly differentiated carcinoma showed positive Gal-3 expression.

\section{CONCLUSION}

The majority of cases of multinodular goiter (MNG) were in females, in the age group 41-50. The proportion of malignancies in MNG was $9.6 \%$. Papillary thyroid carcinoma was the commonest malignancy. Gal-3 can be used as an adjuvant to histopathology for the diagnosis of papillary thyroid carcinoma especially the classic variant and microcarcinoma.

\section{KEY WORDS}

Multinodular Goiter, Thyroid Carcinoma, Galectin-3, Histopathology, Immunohistochemistry

HOW TO CITE THIS ARTICLE: Sreeja K, Pothen L, Sankar S. Proportion and galectin 3 expression of thyroid malignancies developing in multinodular goiter. J. Evolution Med. Dent. Sci. 2019;8(12):930-936, DOI: 10.14260/jemds/2019/207

\section{BACK GROUND}

Thyroid disorders are common worldwide. About twelve percent of Indian adults have palpable goitre. Kerala is endemic for thyroid diseases. Multinodular goiter (MNG) is the most common of all the disorders of the thyroid gland. It is traditionally thought to be a benign disease with an incidence of malignancy of less than $5 \%$ as compared to a solitary nodule of thyroid. Recent studies, however, suggest a higher risk of malignancy in patients with multinodular goiter (7-17\%). Based on the National Cancer Registry Program reports of India, Thiruvananthapuram had the highest relative frequency of cases of thyroid cancer among all cancer cases enrolled in the hospital registry, $1.99 \%$ among males and $5.71 \%$ among females.

'Financial or Other Competing Interest': None.

Submission 22-12-2018, Peer Review 06-03-2019,

Acceptance 13-03-2019, Published 25-03-2019.

Corresponding Author:

Sreeja K,

Resident,

Department of Pathology,

Government Medical College,

Kottayam, Kerala, India.

E-mail:drsreejak@gmail.com

DOI: $10.14260 /$ jemds/2019/207
Papillary carcinoma is the commonest malignancy developing in multinodular goiter followed by follicular carcinoma. Tissue biopsy and routine H\&E staining are the gold standard in the diagnosis of thyroid nodules.

Immunohistochemistry is the most commonly used method to complement the assessment by histopathological examination. The benefit of using Galectin- 3 as a diagnostic marker for thyroid cancer has recently attracted considerable attention, and it has been the most investigated molecule for diagnosing thyroid cancers. Also, the use of Galectin -3 as a target for therapy, has become a growing area of clinical study. This study is therefore conducted to find out the proportion and types of malignancy developing in multinodular goitre and to find out the prospects of Galectin 3 as a specific marker for thyroid malignancy.

\section{MATERIALS AND METHODS}

A cross sectional study was carried out for a period of 1 year from June 2017 till June 2018 in the Department of Pathology, Government Medical College, Kottayam. Total Thyroidectomy specimens received in the Department of Pathology during the study period and histopathologically diagnosed as multinodular Goiter or malignancy in multinodular goiter were included in the study. Cases without proper data, cases 
of thyroid malignancy not associated with multinodular goiter were excluded.

The proportion of malignancies in multinodular goiter varies from 7 to $17 \%$ in different studies. In a study conducted by Gandolfi PP et al the incidence of thyroid carcinoma in multinodular goiter was $13.7 \%$. Considering the proportion of $13.7 \%$ with $95 \%$ confidence interval, 510 patients were studied.

\section{Study Procedure}

Gross examination of the thyroidectomy specimens received were done. Nodular and irregularly enlarged specimens with microscopy showing features of nodular colloid goiter were included. Appropriate bits of tissue, representative of areas to be studied, like grey white areas, granular areas, partially or fully encapsulated areas were taken along with the surrounding normal looking areas. All specimens were fixed in formalin and embedded in paraffin, sections taken and stained with Haematoxylin and Eosin (H\&E) and microscopic examination was done. The gold standard was the histopathological diagnosis.

Immunohistochemical (IHC) staining was done with PathnSitu rabbit monoclonal Gal-3 antibody on histologic sections of the normal tissue with the tumour.

\section{Immunohistochemical Scoring}

The immunohistochemical scoring was based on the guidelines followed by Weber $\mathrm{KB}$ et al. The staining intensity (I score) was graded on a scale of 0 to 3 where $0,1+, 2+$, and $3+$ denote no staining, weak, moderate and intense staining respectively. The proportion of stained cells (P score) were interpreted as $1+(<5 \%$ of cells $), 2+(5 \%$ to $50 \%$ of cells $)$ and $3+(>50 \%$ of cells $)$. As per the guidelines, cases that showed specific cytoplasmic staining of more than $5 \%$ of the tumour cells, regardless of the intensity, were scored as positive for Gal-3.

\section{Data Management and Analysis}

The data was entered in Microsoft excel and further statistical analysis was done using SPSS software (version 24). Descriptive statistics were reported as mean and standard deviation for the continuous variables, number and percentages for the categorical variables. Chi-square test was used to test the association between study variables. $P$ value less than 0.005 was considered statistically significant.

\section{RESULTS}

A total of 510 cases of multinodular goiter were studied. The youngest patient in the study group was 13-year-old and the oldest 85-year-old. 166 cases (32.55\%) belonged to the age group of 41-50 years. The study group consisted of 471 females (92.4\%) and 39 males (7.6\%) with female to male ratio of 12.08: 1 . The maximum number of malignancies was in the $41-50$ years age group (40.8\%). Of the 49 cases of malignancy in MNG, 43 were females (87.8\%) and 6 were males (12.2\%).

\section{Proportion of Malignancies in Multinodular Goiter}

Out of 510 cases of multinodular goiter, 49 (9.6\%) cases showed malignancy.

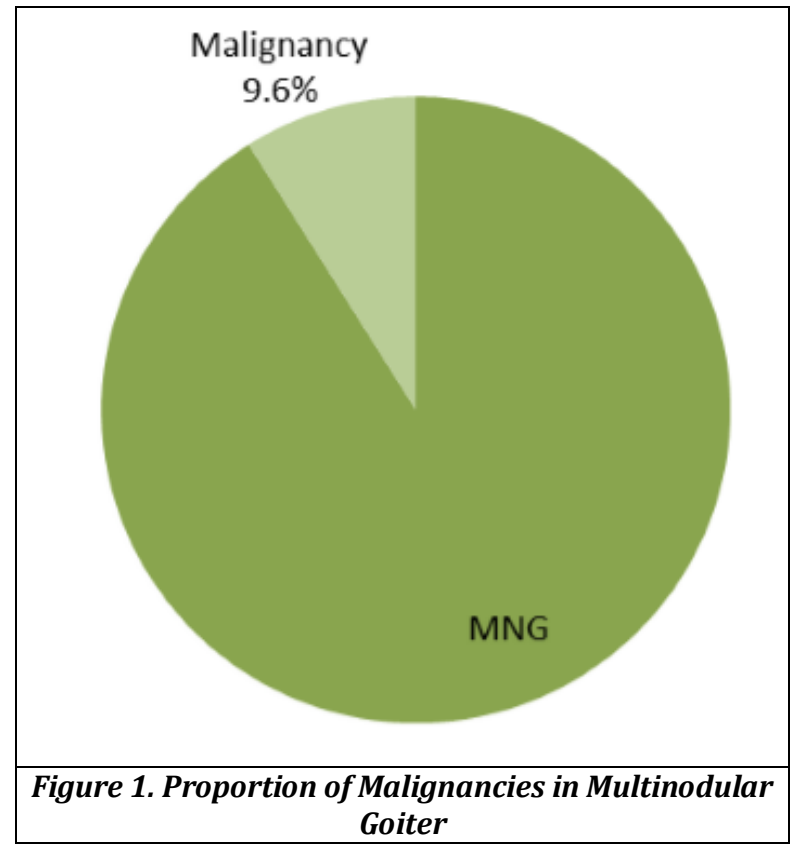

Types of Malignancies in MNG

The different malignancies in MNG, and the number and percentage of cases in each category were as follows:

\begin{tabular}{|c|c|c|c|}
\hline $\begin{array}{c}\text { Serial } \\
\text { No. }\end{array}$ & $\begin{array}{c}\text { Type of } \\
\text { Malignancy }\end{array}$ & $\begin{array}{c}\text { No. of } \\
\text { Cases }\end{array}$ & Percentage \\
\hline 1 & $\begin{array}{c}\text { Papillary Thyroid } \\
\text { Carcinoma (Classic) }\end{array}$ & 23 & $46.94 \%$ \\
\hline 2 & Follicular Variant of PTC & 12 & $24.49 \%$ \\
\hline 3 & Microcarcinoma, PTC & 9 & $18.37 \%$ \\
\hline 4 & $\begin{array}{c}\text { Follicular Carcinoma, } \\
\text { Widely Invasive }\end{array}$ & 2 & $4.08 \%$ \\
\hline 5 & $\begin{array}{c}\text { Follicular Carcinoma, } \\
\text { Minimally Invasive }\end{array}$ & 1 & $2.04 \%$ \\
\hline 6 & Anaplastic Carcinoma & 1 & $2.04 \%$ \\
\hline 7 & $\begin{array}{c}\text { Poorly Differentiated } \\
\text { Carcinoma }\end{array}$ & 1 & $2.04 \%$ \\
\hline \multicolumn{4}{|c|}{ Table 1. Types of Malignancies in MNG } \\
\hline
\end{tabular}

\begin{tabular}{|c|c|c|c|}
\hline $\begin{array}{c}\text { Age } \\
\text { Group }\end{array}$ & $\begin{array}{c}\text { Papillary Thyroid } \\
\text { Carcinoma } \\
\mathbf{n = 4 4}\end{array}$ & $\begin{array}{c}\text { Others } \\
\mathbf{n = 5}\end{array}$ & Total \\
\hline $21-30$ & $4(9.1 \%)$ & $0(0 \%)$ & $4(8.2)$ \\
\hline $31-40$ & $10(22.7 \%)$ & $0(0 \%)$ & $10(20.4)$ \\
\hline $41-50$ & $18(40 \%)$ & $2(40 \%)$ & $20(40.8)$ \\
\hline $51-60$ & $6(13.6 \%)$ & $0(0 \%)$ & $6(12.2)$ \\
\hline $61-70$ & $6(13.6 \%)$ & $1(20 \%)$ & $7(14.3)$ \\
\hline $81-90$ & $0(0 \%)$ & $2(40 \%)$ & $2(4.1)$ \\
\hline Table 2. Comparison of Age Group of PTC With That of \\
Other Malignancies \\
\hline
\end{tabular}

Table 1 describes the types of malignancies and Table 2 gives the comparison of age group of PTC with that of other malignancies. Of the 49 malignancies, 44 were variants of papillary thyroid carcinoma (PTC). The majority of cases of PTC were in the age group 41-50. The maximum percentage of cases in the other category (Follicular, Anaplastic and Poorly differentiated carcinoma) were in the above 60 years age group. A significant association was observed between these variables $(\mathrm{p}=0.001)$.

Table 3 gives the distribution of cases of Papillary Thyroid Carcinoma according to tumour size as compared to other 
malignancies. $19(43.2 \%)$ of the 44 cases of PTC were T 2 , that is with tumour size more than $2 \mathrm{~cm}$ but not more than 4 $\mathrm{cm}$, limited to thyroid. $4(80 \%)$ of the 5 cases in the other malignant category were T3a, tumour size more than $4 \mathrm{~cm}$, limited to thyroid. Statistically significant association was observed between these variables $(\mathrm{p}=0.005)$.

\begin{tabular}{|c|c|c|c|}
\hline Tumour Size & PTC & Others & Total \\
\hline Less Than 1 cm -T1a & $9(20.5 \%)$ & $0(0 \%)$ & $9(18.4)$ \\
\hline $\begin{array}{c}\text { More Than } 1 \mathrm{cms} \text { but Not } \\
\text { More Than } 2 \mathrm{cms} \text { in } \\
\text { Greatest Dimension, } \\
\text { Limited to The Thyroid }\end{array}$ & $10(22.7 \%)$ & $1(20 \%)$ & $11(22.4)$ \\
\hline $\begin{array}{c}\text { More Than } 2 \mathrm{cms} \text { But Not } \\
\text { More Than } 4 \mathrm{cms} \text {, Limited } \\
\text { to Thyroid- T } 2\end{array}$ & $19(43.2 \%)$ & $0(0 \%)$ & $19(38.8)$ \\
\hline $\begin{array}{c}\text { More Than } 4 \mathrm{cms} \text {, Limited } \\
\text { to Thyroid-T3a }\end{array}$ & $5(11.4 \%)$ & $4(80 \%)$ & $9(18.4)$ \\
\hline $\begin{array}{c}\text { Tr Extends Beyond the } \\
\text { Thyroid Capsule; to Soft } \\
\text { Tissue-T4a }\end{array}$ & $1(2.2 \%)$ & $0(0 \%)$ & $1(2.0)$ \\
\hline $\begin{array}{c}\text { Table 3. Distribution of Cases of Papillary Thyroid } \\
\text { Carcinoma According to Tumour Size as Compared to } \\
\text { Other Malignancies }\end{array}$ \\
\hline
\end{tabular}

Galectin-3 Expression in Thyroid Malignancies

Of the 49 cases of malignancy, 39 (79.6\%) showed a positive Gal-3 expression and $10 \quad(20.4 \%)$ showed negative expression. The Gal-3 expression in the different malignancies are given in table 4.

\begin{tabular}{|c|c|c|c|c|}
\hline Galectin-3 & $\begin{array}{c}\text { Papillary } \\
\text { Carcinoma } \\
\text { All Variant } \\
\mathbf{n = 4 4}\end{array}$ & $\begin{array}{c}\text { Follicular } \\
\text { Carcinoma } \\
\mathbf{n = 3}\end{array}$ & $\begin{array}{c}\text { Anaplastic } \\
\text { Carcinoma } \\
\mathbf{n = 1}\end{array}$ & $\begin{array}{c}\text { Poorly } \\
\text { Differentiated } \\
\text { Carcinoma } \\
\mathbf{n = 1}\end{array}$ \\
\hline Positive & $36(82 \%)$ & $1(33 \%)$ & $1(100 \%)$ & $1(100 \%)$ \\
\hline Negative & $8(18 \%)$ & $2(67 \%)$ & 0 & 0 \\
\hline Table 4. Galectin-3 Expression in Thyroid Malignancies \\
\hline
\end{tabular}

\section{GAL-3 Expression in Papillary Carcinoma}

Out of the 23 cases of Classic Papillary thyroid carcinoma, Galectin-3 showed positive expression in 20 (87\%) and negative expression in $3(13 \%)$ cases. $8(67 \%)$ of the 12 cases of follicular variant of papillary carcinoma showed Galectin 3 positivity and $4(33 \%)$ were negative. 8 (89\%) of the 9 cases of Papillary microcarcinoma showed positive Galectin 3 expression and $1(11 \%)$ was negative.

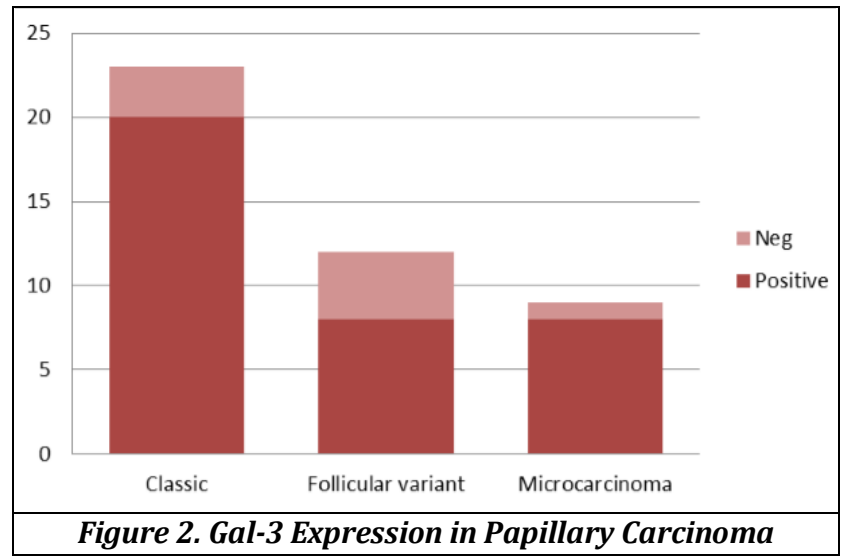

Out of the 2 cases of widely invasive follicular carcinoma, one showed positive galectin 3 expression and one was negative. One follicular carcinoma which was minimally invasive showed negative galectin 3 expression. So out of 3 cases of follicular carcinoma, one showed positive Galectin 3 expression(33\%) and 2 had negative expression (67\%).

Galectin 3 Expression in Anaplastic Thyroid Carcinoma and Poorly Differentiated Carcinoma

There was one case each of Anaplastic Carcinoma and Poorly differentiated Carcinoma.

Galectin 3 expression was positive in both these cases.

\section{Intensity of GAL-3 Expression in Thyroid Malignancies}

The intensity score or I score in the different malignancies is given in table 5 and the proportion score of the thyroid malignancies is given in table 6 .

\begin{tabular}{|c|c|c|c|c|}
\hline I Score & $\begin{array}{c}\text { Papillary } \\
\text { Carcinoma } \\
(\mathbf{n = 4 4 )}\end{array}$ & $\begin{array}{c}\text { Follicular } \\
\text { Carcinoma } \\
(\mathbf{n = 3})\end{array}$ & $\begin{array}{c}\text { Anaplastic } \\
\text { Carcinoma } \\
\mathbf{( n = 1 )}\end{array}$ & $\begin{array}{c}\text { Poorly } \\
\text { Differentiated } \\
\text { Carcinoma(n=1) }\end{array}$ \\
\hline 0 & $3(6.8 \%)$ & $0(0 \%)$ & $0(0 \%)$ & $0(0 \%)$ \\
\hline $1+$ & $15(34.1 \%)$ & $3(100 \%)$ & $0(0 \%)$ & $1(100 \%)$ \\
\hline $2+$ & $19(43.2 \%)$ & $0(0 \%)$ & $1(100 \%)$ & $0(0 \%)$ \\
\hline $3+$ & $7(15.9 \%)$ & $0(0 \%)$ & $0(0 \%)$ & $0(0 \%)$ \\
\hline \multicolumn{5}{|c|}{ Table 5 } \\
\hline
\end{tabular}

\begin{tabular}{|c|c|c|c|c|}
\hline P Score & $\begin{array}{c}\text { Papillary } \\
\text { Carcinoma } \\
\mathbf{n = 4 4}\end{array}$ & $\begin{array}{c}\text { Follicular } \\
\text { Carcinoma } \\
\mathbf{n = 3}\end{array}$ & $\begin{array}{c}\text { Anaplastic } \\
\text { Carcinoma } \\
\mathbf{n = 1}\end{array}$ & $\begin{array}{c}\text { Poorly } \\
\text { Differentiated } \\
\mathbf{n = 1}\end{array}$ \\
\hline $\begin{array}{c}1+(\mathrm{less} \\
\text { than } 5 \% \\
\text { cells })\end{array}$ & $\begin{array}{c}8 \\
(18.2 \%)\end{array}$ & $\begin{array}{c}2 \\
(67 \%)\end{array}$ & $\begin{array}{c}0 \\
(0 \%)\end{array}$ & $\begin{array}{c}0 \\
(0 \%)\end{array}$ \\
\hline $\begin{array}{c}2+(5-50 \% \\
\text { cells })\end{array}$ & $10(22.7 \%)$ & $1(33 \%)$ & $0(0 \%)$ & $\begin{array}{c}1 \\
(100 \%)\end{array}$ \\
\hline $\begin{array}{c}3+(>50 \% \\
\text { cells })\end{array}$ & $\begin{array}{c}26 \\
(59.1 \%)\end{array}$ & $\begin{array}{c}0 \\
(0 \%)\end{array}$ & $\begin{array}{c}1 \\
(100 \%)\end{array}$ & $\begin{array}{c}0 \\
(0 \%)\end{array}$ \\
\hline \multicolumn{5}{|c|}{ Table 6 } \\
\hline
\end{tabular}

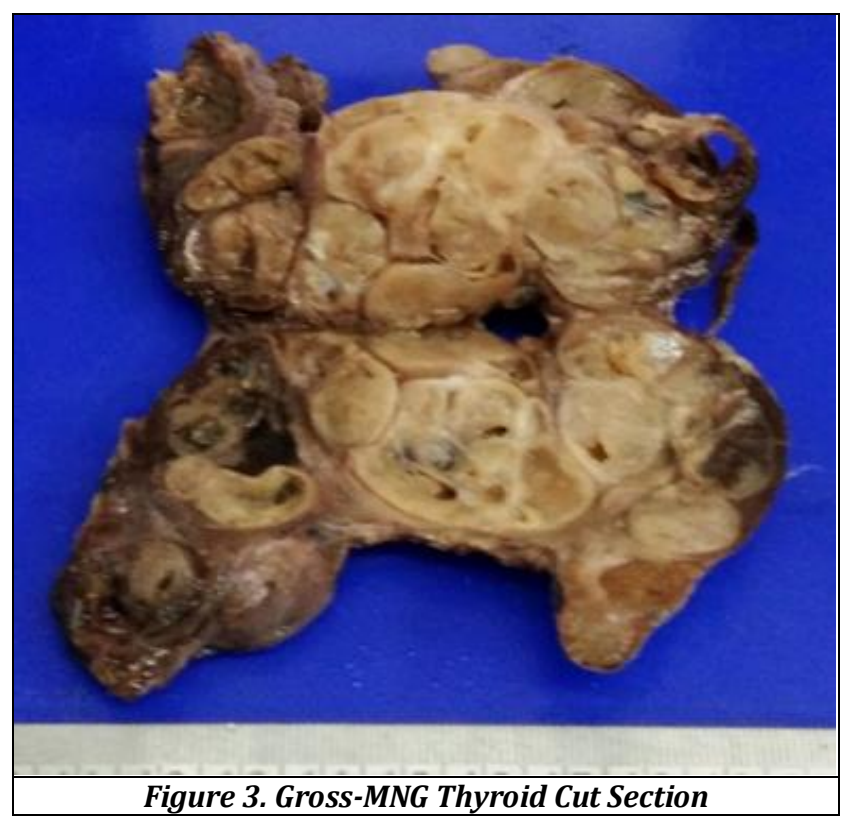

\section{GAL-3 Expression in Follicular Carcinoma}




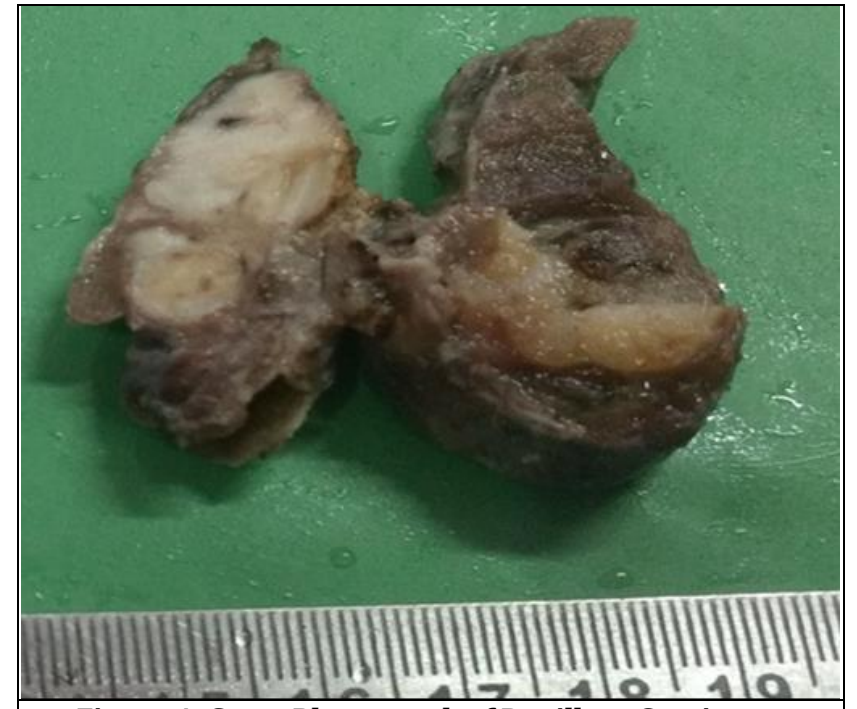

Figure 4. Gross Photograph of Papillary Carcinoma Thyroid in MNG

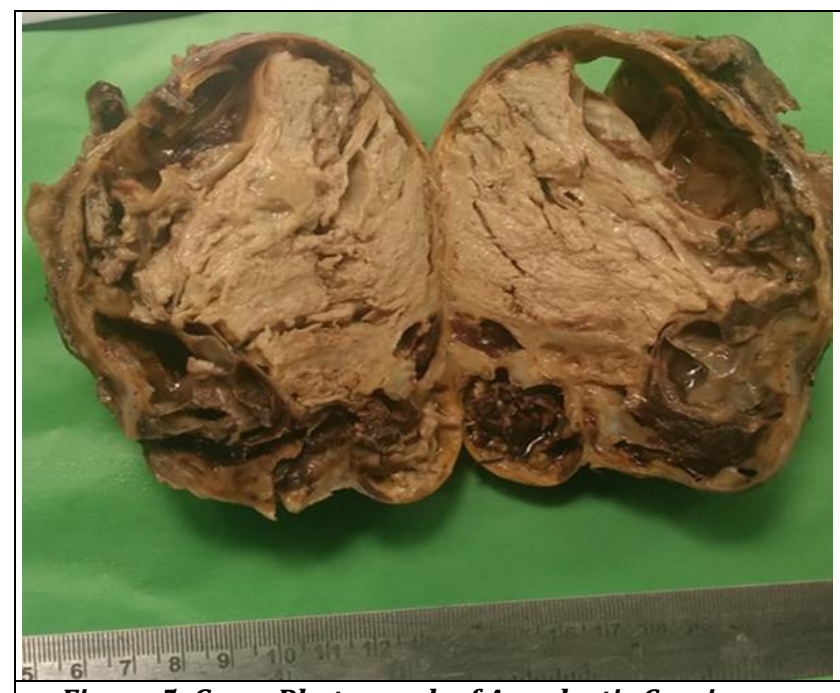

Figure 5. Gross Photograph of Anaplastic Carcinoma Thyroid in MNG

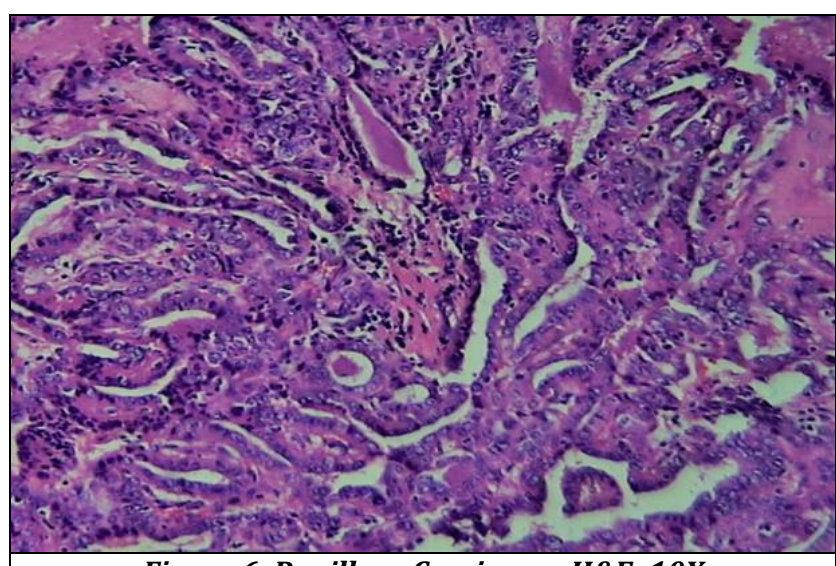

Figure 6. Papillary Carcinoma H\&E- 10X

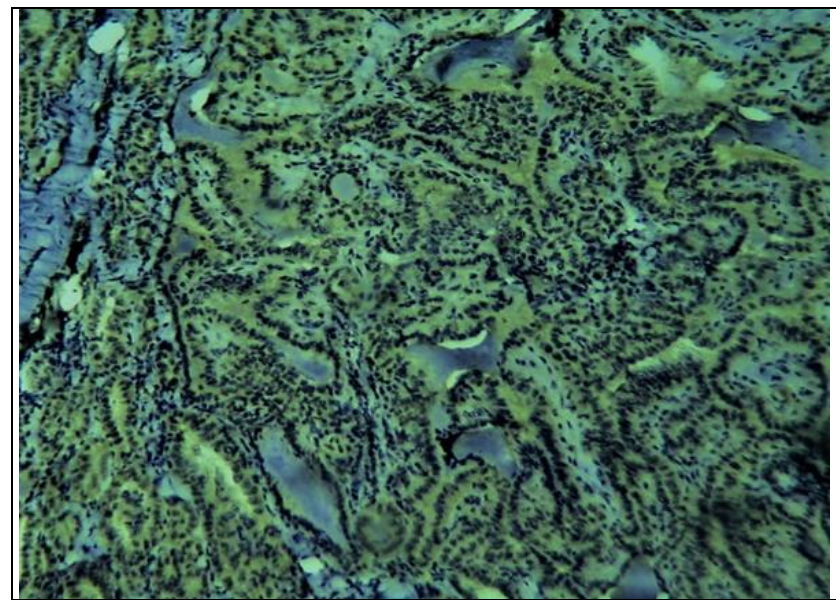

Figure 7. Galectin-3 Expression in Papillary Carcinoma, Classic Type-3+

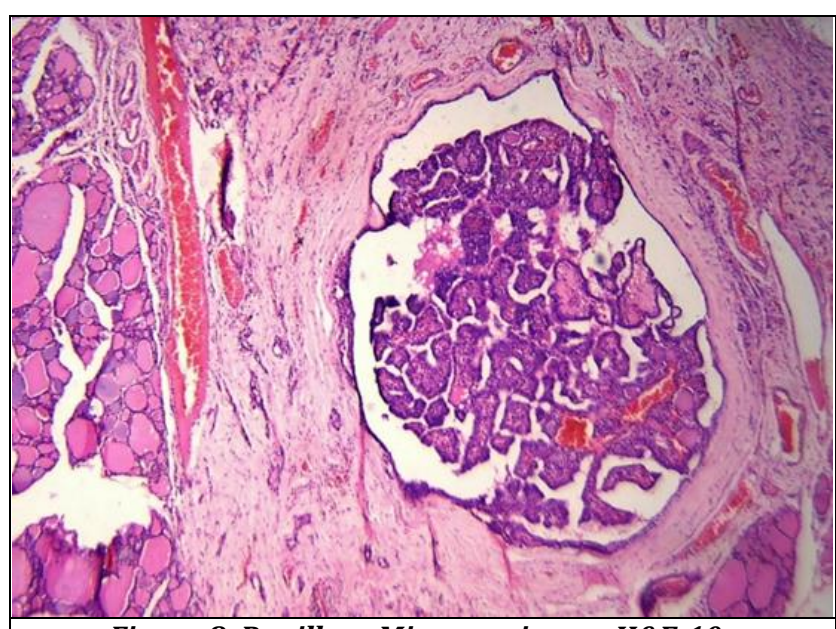

Figure 8. Papillary Microcarcinoma H\&E-10x

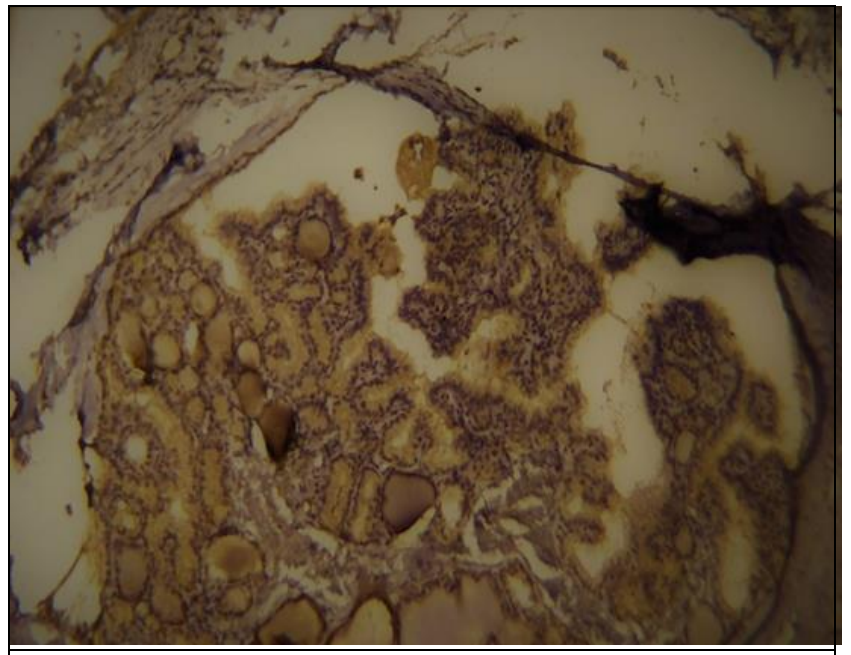

Figure 9. Galactin-3 Expression in Microcarcinoma-2+ 

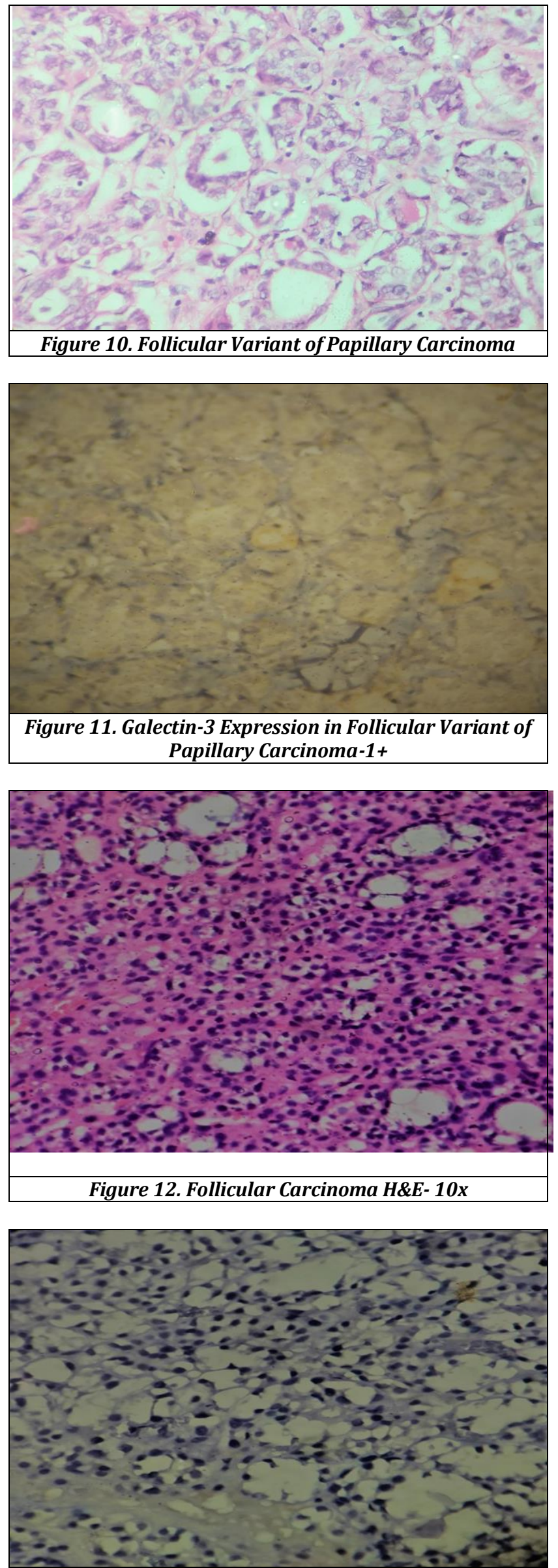

Figure 13. Galectin-3 in Follicular Carcinoma- Negative

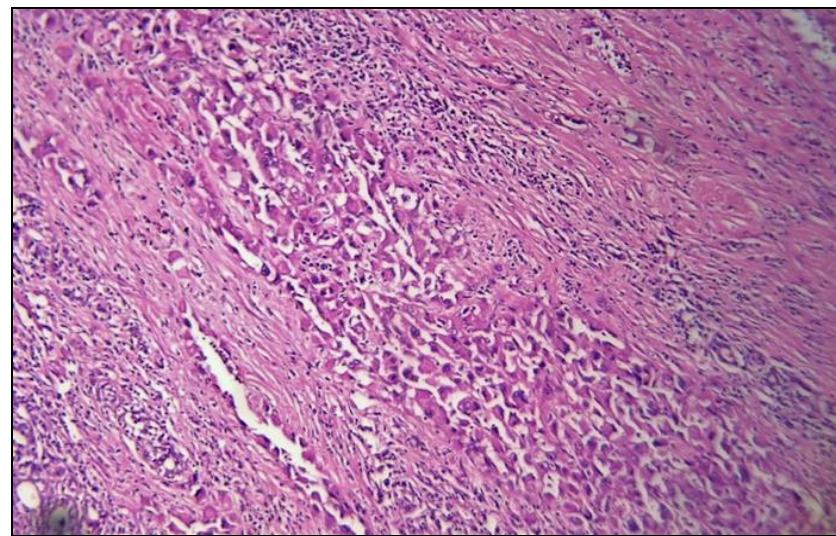

Figure 14. Poorly Differentiated Carcinoma-H\&E- 40X

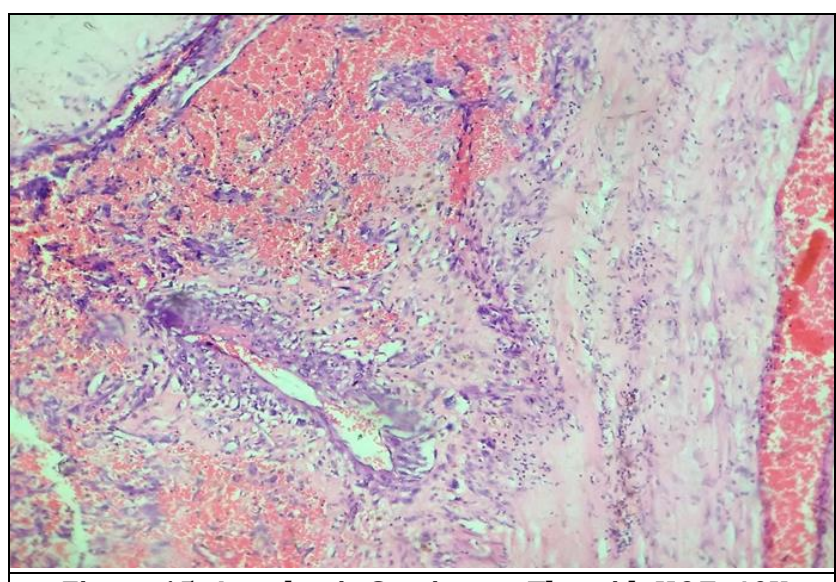

Figure 15. Anaplastic Carcinoma Thyroid-H\&E- 40X

\section{DISCUSSION}

The proportion of malignancies in multinodular goiter in the present study was $9.6 \%$. The proportion in our study is comparable to the study conducted by Hanumantha et al ${ }^{1}$ and Nadeem et $\mathrm{al}^{2}$ where the incidences were $10 \%$ and $10.2 \%$ respectively.

\begin{tabular}{|c|c|c|c|}
\hline Study & $\begin{array}{c}\text { Year of } \\
\text { Study }\end{array}$ & $\begin{array}{c}\text { No. of Cases } \\
\text { of MNG }\end{array}$ & Proportion \\
\hline${\text { Hanumantha et } \mathrm{al}^{1}}^{1}$ & $2007-2010$ & 100 & 10 \\
\hline Nadeem et al $^{2}$ & $2010-2012$ & 98 & 10.2 \\
\hline Present study & $2017-2018$ & 510 & 9.6 \\
\hline
\end{tabular}

Table 7. Comparison of Proportion of Malignancies in MNG of Study Group with Other Studies

Among the 49 cases of malignancy in MNG, the most common was papillary thyroid carcinoma with 44 cases, of which 23 cases are classic PTC (46.9\%), followed by 12 cases of follicular variant and 9 cases of Papillary microcarcinoma. There were 3 cases of Follicular carcinoma of which 2 cases were widely invasive follicular carcinoma and one case of minimally invasive $(2.04 \%)$. There was one case each of Anaplastic and poorly differentiated carcinoma (2.04\% each). The results of the present study are comparable to the studies by Hanumantha et al, ${ }^{1}$ Shreshta et al, ${ }^{3}$ Nadeem et al,, Gandolfi et al, ${ }^{4}$ Rovena Bode et al. ${ }^{5}$ 


\begin{tabular}{|c|c|c|c|c|c|c|}
\hline $\begin{array}{l}\vec{E} \\
\vec{\omega}\end{array}$ & 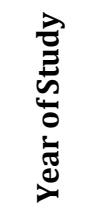 & 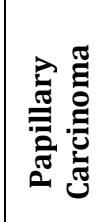 & 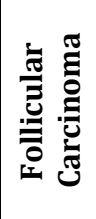 & 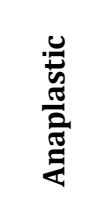 & 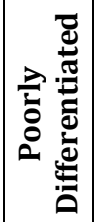 & $\frac{n}{0}$ \\
\hline Shreshta et al ${ }^{3}$ & $\begin{array}{l}2011- \\
2014\end{array}$ & $84.61 \%$ & $7.69 \%$ & $7.69 \%$ & - & \\
\hline $\begin{array}{c}\text { Hanumanthappa } \\
\text { et al }^{1}\end{array}$ & $\begin{array}{l}2007- \\
2010\end{array}$ & $60 \%$ & $20 \%$ & - & - & $20 \%$ \\
\hline Nadeem et al ${ }^{2}$ & & $71.4 \%$ & $14.2 \%$ & $9.5 \%$ & - & $4.7 \%$ \\
\hline $\begin{array}{c}\text { Rovena Bode et } \\
\mathrm{al}^{5}\end{array}$ & $\begin{array}{l}2010- \\
2013\end{array}$ & $70 \%$ & $13 \%$ & $1.4 \%$ & - & $12.8 \%$ \\
\hline Gandolfi et al ${ }^{4}$ & $\begin{array}{l}1995- \\
2002\end{array}$ & $72 \%$ & $4 \%$ & $8 \%$ & - & $16 \%$ \\
\hline Present Study & $\begin{array}{l}2017- \\
2018 \\
\end{array}$ & $89.8 \%$ & $6.12 \%$ & $2.04 \%$ & $2.04 \%$ & \\
\hline
\end{tabular}

Table 8. Comparison of Types of Malignancy in MNG of Study Group with Other Studies

Among the 43 cases of Papillary Carcinoma, classic or conventional type was the most common with 23 cases, followed by follicular variant with 12 cases and Papillary microcarcinoma 9 cases.

In this study, out of 44 cases of papillary thyroid carcinoma, Gal-3 expression was positive in 36 cases (82\%) and negative in 8 cases (18\%). The results are comparable to the studies by Sumana et $\mathrm{al}^{6}$ and Cvejic et al. ${ }^{7}$

Gal-3 expression was noted in 20 out of 23 cases (87\%) of classic PTC. Comparable results were obtained in studies of Matos et al. Regarding FVPTC, Gal-3 positivity ranged from $33 \%$ to $100 \%$ in various studies. $8(67 \%)$ of the 12 cases of follicular variant of papillary carcinoma showed Gal-3 positivity and 4 (33\%) were negative. In this study, 8 (89\%) of the 9 cases of Papillary microcarcinoma showed positive Gal-3 expression and 1 (11\%) was negative. This is comparable to the studies by Cvejic et al. ${ }^{7}$ The high positive expression of Gal-3 in microcarcinomas, will enable it's use as a diagnostic adjuvant.

In this study out of 3 cases, only one case (33\%) of FTC showed positive Gal-3 Expression. Expression of Gal -3 ranged from $20 \%$ to $100 \%$ in cases of FTC, in different studies. The difference may partially be due to the subjective criteria used in assessing positive expression.

In this study, there was only one case each of Anaplastic and Poorly differentiated carcinoma. Both showed positive Galectin 3 expression. The intensity of staining was strong in anaplastic and moderate in poorly differentiated carcinoma and the results are comparable to the study by Sumana et al. 6

The percentage of positive Gal-3 expression was high in papillary thyroid carcinoma. Multivariate analysis and Logistical regression analysis were done. But none of the variables was significant. The small sample size of the malignancies was the limitation.

\begin{tabular}{|c|c|c|c|c|}
\hline Study & PTC & $\begin{array}{l}\text { Follicular } \\
\text { Carcinoma }\end{array}$ & ATC $n=1$ & PD $C n=1$ \\
\hline Weber et al ${ }^{8}$ & $92 \%$ & $44 \%$ & - & - \\
\hline Sumana et al & $91.3 \%$ & $50 \%$ & $100 \%$ & $100 \%$ \\
\hline Present Study & $82 \%$ & $33 \%$ & $100 \%$ & $100 \%$ \\
\hline
\end{tabular}

Table 9. Comparative Analysis of Galectin-3 Positive Expression in Thyroid Malignancies

\begin{tabular}{|c|c|c|c|c|}
\hline Study & $\begin{array}{c}\text { Year of } \\
\text { Study }\end{array}$ & $\begin{array}{c}\text { Classic } \\
\text { PTC }\end{array}$ & $\begin{array}{c}\text { Follicular } \\
\text { Variant }\end{array}$ & $\begin{array}{c}\text { Micro } \\
\text { Carcinoma }\end{array}$ \\
\hline Sumana et $\mathrm{al}^{6}$ & 2015 & $93 \%$ & $75 \%$ & $100 \%$ \\
\hline Present Study & $2017-2018$ & $87 \%$ & $67 \%$ & $89 \%$ \\
\hline \multicolumn{4}{|c|}{ Table 10. Comparative Analysis of Gal-3 Expression in } \\
Variants of PTC \\
\hline
\end{tabular}

\section{CONCLUSION}

The proportion of malignancies in MNG was 9.6\%. The majority $(89.8 \%)$ were cases of papillary thyroid carcinoma, the others were follicular, anaplastic and poorly differentiated carcinomas. The classic type of PTC was the main variant seen, followed by follicular variant and papillary microcarcinoma.

$79.6 \%$ of the malignancies showed positive Gal-3 expression. $82 \%$ cases of papillary thyroid carcinoma showed positive Gal-3 expression. The Gal-3 expression was low in follicular carcinoma (33\%). Majority of cases of classic papillary thyroid carcinoma and papillary microcarcinoma showed positive Gal-3 expression. Gal- 3 can be used as an adjuvant to histopathology in diagnosing classic and micropapillary variants of papillary thyroid carcinoma. Gal-3 has got very limited role in the diagnosis of follicular carcinoma.

Gal-3 was positive in anaplastic and poorly differentiated carcinoma. But this needs to be further studied as the sample size was very low in this study.

This study thus attests the fact that standard histopathological examination using routine $\mathrm{H} \& \mathrm{E}$ sections remains the gold standard to diagnose the malignant nature of thyroid tumours.

\section{ACKNOWLEDGEMENTS}

I express my heartfelt thanks and gratitude to Dr. Sankar S, Head of Department, Department of Pathology, Government Medical College, Kottayam and my guide Dr. Lillykutty Pothen for their support and help. I am thankful to all my teachers in the Department of Pathology, Government Medical College, Kottayam as well as fellow postgraduate students and my friends for their whole hearted co-operation, help and encouragement.

\section{REFERENCES}

[1] Hanumanthappa MB, Gopinathan S, Suvarna R, et al. The incidence of malignancy in multi-nodular goitre: a prospective study at a tertiary academic centre. Journal of Clinical and Diagnostic Research 2012;6(2):267-70.

[2] Nadeem K, Akhtar N, Tarar JM. Thyroid malignancy in multi nodular goiter: incidence, a retrospective study in southern Punjab. Professional Med J 2013;20(4):587-90.

[3] Shrestha D, Shrestha S. The incidence of thyroid carcinoma in multinodular goiter: a retrospective study. JCMS Nepal 2014;10(4):18-21.

[4] Gandolfi PP, Frisina A, Raffa M, et al. The incidence of thyroid carcinoma in multi-nodular goiter: a retrospective analysis. Acta BioMedica Ateneo Parmense 2004;75(2):114-7.

[5] Bode R, Celiku E, Dracini X, et al. Thyroid carcinoma in multinodular goiter. IOSR Journal of Dental and Medical Sciences (IOSR-JDMS) 2016;15(11):118-22. 
[6] Sumana BS, Shashidhar S, Shivarudrappa AS. Galectin3 immunohistochemical expression in thyroid neoplasms. Journal of Clinical and Diagnostic Research 2015;9(11):EC07-EC11.

[7] Cvejic D, Savin S, Petrovic I, et al. Galectin-3 expression in papillary microcarcinoma of the thyroid. Histopathology 2005;47(2):209-14.

[8] Weber KB, Shroyer KR, Heinz DE, et al. The use of a combination of galectin-3 and thyroid peroxidase for the diagnosis and prognosis of thyroid cancer. Am J Clin Pathol 2004;122(4):524-31.
[9] De Matos PS, Ferreira AP, de Oliveira FF, et al. Usefulness of HBME-1, cytokeratin 19 and galectin-3 immunostaining in the diagnosis of thyroid malignancy. Histopathology 2005;47(4):391-401.

[10] Zhou Y, Chen ZH, Lu BH, et al. Diagnostic significance of Ki67, CK19, Galectin-3 and HBME-1 expression for papillary thyroid microcarcinoma. Biomedical Research 2017;28(9):4002-6. 